\title{
REFERENCES
}

Artom, C. \& Fishman, W. H. (1943a). J. biol. Chem. 148, 405.

Artom, C. \& Fishman, W. H. (1943b). J. biol. Chem. 148, 423.

Best, C. H. \& Campbell, J. (1936). J. Physiol. 86, 190.

Best, C. H., Lucas, C. C., Patterson, J. M. \& Ridout, J. H. (1946). Biochem. J. 40, 368.

Bollman, J. L. \& Flock, E. V. (1946). Fed. Proc. 5, 218.

Bollman, J. L., Flock, E. V. \& Berkson, J. (1948). Proc. Soc. exp. Biol., N.Y., 67, 308.

Chaikoff, I. L. (1942). Physiol. Rev. 22, 291.

Channon, H. J. \& Wilkinson, H. (1936). Biochem. J. 30, 1033.

Ennor, A. H. \& Stocken, L. A. (1948). Biochem. J. 42 , 549.

Fisher, R.A.(1944). Statistical Methods for Research Workers, 9th ed. Edinburgh: Oliver and Boyd.

Fishman, W. H. \& Artom, C. (1944). J. biol. Chem. 154, 109.

Fishman, W. H. \& Artom, C. (1946) J.biol. Chem. 164, 307.

Flock, E., Bollman, J. L. \& Mann, F. C. (1936). J. biol. Chem. 115, 179.

Hevesy, G. (1938). Enzymologia, 5, 138.
Hodge, H. C., MacLachlan, P. L., Bloor, W. R., Stoneburg, C. A., Oleson, M. C. \& Whitehead, R. (1941). J. biol. Chem. $139,897$.

Hodge, H. C., MacLachlan, P. L., Bloor, W. R., Welch, E. A., Kornberg, S. L. \& Falkenheim, M. (1947). J. biol. Chem. 169, 707.

Kaplan, N. O. \& Greenberg, D. M. (1944a). J. biol. Chem. 156, 511.

Kaplan, N. O. \& Greenberg, D. M. (1944b). J. biol. Chem. 156, 525.

Kaplan, N. O. \& Greenberg, D. M. (1944c). J. biol. Chem. 156, 543 .

Loureiro, de, J. A. (1931). Arquito Patalog. 3, 72.

MacLachlan, P. L. (1944). J. biol. Chem. 152, 391.

Ozaki, J. (1927). Biochem. Z. 189, 233.

Perlman, I., Chaikoff, I. L. (1939). J. biol. Chem. 127, 211. Popják, G. (1943). Biochem. J. 37, 468.

Taurog, A., Entenman, C., Fries, B. A. \& Chaikoff, I. L. (1944). J. biol. Chem. 155, 19.

Yasuda, M. (1931). J. biol. Chem. 94, 401.

Zilversmit, D. B., Chaikoff, I. L. \& Entenman, C. (1948). J. biol. Chem. 172, 637.

\section{Renal Function as Affected by Experimental Unilateral Kidney Lesions}

\section{THE EFFECT OF CYANIDE}

\author{
By T. F. NICHOLSON, Department of Pathological Chemistry, University of Toronto
}

(Received 14 February 1949)

An earlier paper (Nicholson, Selby \& Urquhart, 1938) described some of the functional changes occurring when a mild degeneration of the cells of the proximal convoluted tubules is produced by sodium tartrate. One effect is an interference with the selective permeability of the tubular cells such that there is back diffusion of substances to which the walls of the tubules are normally impermeable (e.g. inulin, creatinine, ferrocyanide). Bobey, Longley, Dickes, Price \& Hayman (1942) reported a similar effect with uranium nitrate. It was thought possible that any substance which caused tubular degeneration or which interfered with tubular function might also produce changes in the permeability of the cells lining the tubules. To test the latter possibility the effect of cyanide has been studied. In the isolated kidney Starling \& Verney (1925) found that cyanide completely inhibits tubular activity and results in the excretion of a urine which is essentially an ultrafiltrate of the plasma, i.e. unchanged glomerular filtrate.

The present experiments show, however, that when cyanide is added to the blood flowing through the kidney in situ its nephrotoxic action is more selective.

\section{METHODS}

\section{Physiological techniques}

Preparation of the animals. Female dogs of from 7 to $8 \mathrm{~kg}$. were used. Under nembutal anaesthesia the femoral artery and vein on both sides and one jugular vein were exposed. The kidneys were exposed through a long mid-line incision, and the renal artery and vein on each side were gently freed from the surrounding perirenal fat. When the cut surfaces had ceased oozing the animal was heparinized. Thin-walled silver cannulae, of approximately the same internal diameters as the vessels in which they were to be used, were inserted into the renal and femoral vessels. The femoral and renal veins and the femoral and renal arteries were joined by moderately thick-walled rubber tubing running through the abdominal cavity. Each length of rubber tubing had a glass $T$ tube inserted in its course so that one end of each $T$ tube was in immediate juxtaposition with the free end of the respective femoral cannula. The side arms of the arterial $T$ tubes were each attached to a mercury manometer. From each venous $T$ tube a short piece of rubber tubing, closed by a pinchcock, led into a $500 \mathrm{ml}$. cylinder. A graduated reservoir contained $1500 \mathrm{ml}$. of heparinized blood, obtained immediately before the experiment from dogs whose blood gave no cross agglutination with that of the experimental animal, was attached by a rubber tube, closed by a pinchcock. to a cannula inserted into the jugular vein. The urinary 
bladder was then opened down the mid-line anteriorly and the ureters catheterized.

Injection of cyanide. The rate of blood flow through the kidneys was determined by placing bull-dog clamps on the femoral veins just distal to the $T$ tubes and simultaneously opening the pinchcocks on the outlet tubes. The blood was allowed to flow into the graduated cylinders for 5-10 min., depending on the rate of flow, and the minute flow measured. At the same time the dog was transfused through the jugular vein at approximately the same rate as the combined outflow from the kidneys. No appreciable change in renal blood pressure or blood flow was noted during the time of measurement. The rate in different animals varied from 40-75 $\mathrm{ml} . / \mathrm{min}$. and was usually constant throughout the period of measurement. Except in a few animals, which were discarded, the rate of blood flow was practically identical for each kidney of the same animal. When the renal blood flow had been determined a continuous fine stream of $0.67 \mathrm{~m}-\mathrm{NaCN}$ solution of $\mathrm{pH} 7 \cdot 4$ was introduced into the blood going to the left kidney at the rate of $0.25 \mathrm{ml}$. for every $100 \mathrm{ml}$. of blood. This gives a concentration of cyanide in the blood of approximately $\mathrm{m} / 600$ as used by Starling \& Verney (1925). The solution was injected through a no. 27 needle inserted through the wall of the rubber tubing connecting the femoral and renal arteries at a point just proximal to the manometer $T$ tube. The needle was connected to a modified Woodyatt pump by $2 \mathrm{ft}$. of pure gum rubber tubing of $\frac{1}{8}$ in. inside diameter and $\frac{1}{16}$ in. wall. With this arrangement the solution could be delivered with a steady flow at rates of 0.1-1.0 $\mathrm{ml} / \mathrm{min}$. Under these conditions complete mixing of the blood and injected fluid takes place. This was shown by some preliminary experiments in which solutions containing $8 \%$ creatinine were injected at the same rate as the cyanide solution. Samples of blood taken from the renal artery contained $20 \mathrm{mg}$. ( $\pm 1 \mathrm{mg}$.) of added creatinine $/ 100 \mathrm{ml}$.

During the period of cyanide injection, which lasted for $13 \mathrm{~min}$., the blood from the renal veins was again run into the graduated cylinders and the blood flow measured, the blood lost being replaced by transfusion from the reservoir. No significant changes in blood flow or blood pressure were produced by the injection of cyanide. The blood from the right kidney was returned at $2 \mathrm{~min}$. intervals to the transfusion reservoir. The cyanided blood from the left kidney was discarded. After discontinuing the cyanide injection the blood flow from the right kidney was again directed into the right femoral vein. That from the left kidney was allowed to flow into the cylinder for a further $2 \mathrm{~min}$. to wash away any traces of cyanide before directing the flow into the left femoral vein.

Collection of urine and blood. Urine was collected under oil in tubes graduated to read to $0.02 \mathrm{ml}$.

Blood was taken with a tight-fitting oiled syringe from the 'arterial' tubing just distal to the renal artery of each kidney in the first four dogs. As there was no essential difference found between the bloods from the two arteries, samples in the remaining dogs were taken from the right 'arterial' tubing just before it entered the abdominal cavity. The blood (already heparinized in the animal) was centrifuged in a completely filled tube (Peters \& Van Slyke, 1931) and all estimations done on the plasma.

Clearance technique. Immediately after the animal was anaesthetized a priming infusion of $1 \mathrm{~g}$. creatinine, $1.5 \mathrm{~g}$. inulin and $25 \mathrm{mg}$. phenol red in $50 \mathrm{ml}$. of $0.89 \%$ saline was given into a vein in the fore-leg at the rate of $10 \mathrm{ml} . / \mathrm{min}$. This was followed by a sustaining infusion of $1 \mathrm{~g}$. creatinine,
$1 \mathrm{~g}$. inulin and $125 \mathrm{mg}$. phenol red in $500 \mathrm{ml} .0 .89 \%$ saline given at the rate of $2 \mathrm{ml} / \mathrm{min}$. This maintained a fairly constant level of the above three substances in the blood for the period during which the clearances were being estimated.

Two consecutive $10 \mathrm{~min}$. clearance tests were made before the injection of cyanide. The 'cyanide' clearances were started $3 \mathrm{~min}$. after the commencement of the cyanide injection and were continued for $10 \mathrm{~min}$. In a few cases the collection was made in two periods of $5 \mathrm{~min}$. each. Blood was collected before and after each clearance period. Clearances of creatinine, inulin, urea and phenol red were estimated for each kidney, and the amount of glucose and chloride in the urine determined. Plasma urea was determined on a specimen taken at about the middle of the experimental period. Plasma creatinine, inulin and phenol red were determined on all specimens. Clearances were calculated by the usual formula $\frac{U \times V}{P}=C$, where $U=$ concentration in the urine in $\mathrm{mg} . / 100 \mathrm{ml} ., V=$ urine flow in ml./min., $P=$ concentration in the plasma in $\mathrm{mg} . / 100 \mathrm{ml}$. and $C=$ amount of plasma 'cleared' in $\mathrm{ml} . / \mathrm{min}$.

\section{Analytical methods}

Plasma. Urea was determined by the method of Van Slyke \& Cullen (1916).

Inulin was estimated by determining the reduction obtained after hydrolysing a tungstic acid filtrate (Van Slyke \& Hawkins, 1928), from which the glucose had been removed by fermentation with washed baker's yeast, with $\mathrm{N}-\mathrm{H}_{2} \mathrm{SO}_{4}$ for $2 \mathrm{hr}$. at $90^{\circ}$. A blank determination was done on plasma obtained before starting the infusions. Reduction was measured by the Harding \& Downs (1933) modification of the Shaffer-Somogyi reagent. Creatinine was determined by the method of Folin \& Wu (1919) using the Evelyn photoelectric colorimeter. Total phenol red was determined by adding $5 \mathrm{ml} .10 \% \mathrm{Na}_{2} \mathrm{CO}_{3}$ solution to $10 \mathrm{ml}$. of a 1 in 10 dilution of plasma and measuring the colour developed in the Evelyn photoelectric colorimeter using a no. 540 filter.

Free phenol red in plasma was calculated using the formula $\frac{X}{M}=K C$ (Grollman, 1925), where $X=\mathrm{mg}$. bound dye $/ 100 \mathrm{ml}$., $M=$ percentage of albumin, $K=0.66$ for dog plasma (Shannon, 1935), $C=\mathrm{mg}$. free dye $/ 100 \mathrm{ml}$. and $\mathrm{l} / n=0.83$ for dog plasma (Shannon, 1935).

Chloride was determined by the titrimetric method of Sendroy (1937), and $\mathrm{pH}$ with the Beckman $\mathrm{pH}$ meter using the glass electrode.

Urine. Urea was estimated as for plasma using 1 in 50 or 1 in 100 dilutions.

Inulin was estimated by the reduction produced on hydrolysis using a 1 in 400 or 1 in 800 dilution of urine. At these dilutions the small amounts of glucose in the urine gave no reduction and the blank was negligible.

Phenol red was estimated as in plasma using dilution of 1 in 400 to 1 in 800 .

Glucose was estimated on $\mathrm{HgSO}_{4}-\mathrm{BaCO}_{3}$ filtrates (West, Scharles \& Peterson, 1929) by determining the decrease in reducing values after fermentation with baker's yeast.

Creatinine was determined on 1 in 400 to 1 in 800 dilutions of urine by the method used for plasma.

Chloride was determined by Sendroy's 'exact' titrimetric method and $\mathrm{pH}$ with the Beckman $\mathrm{pH}$ meter with a glass electrode. 


\section{RESULTS}

Table 1 gives all the findings in a typical experiment (dog 5). In Table 2, the results obtained on both right and left kidneys during the period in which the blood containing $\mathrm{M} / 600$ cyanide was flowing through the left kidney are given.
It will be noted that cyanide has little effect on glucose reabsorption. Urine volume is increased from about 5 to approximately 15 times, but never approaches the volume of the glomerular filtrate. Urine chloride and $\mathrm{pH}$ are the same as that of the plasma. The clearances of inulin and creatinine are unaffected, but the clearance of urea is decreased to

Table 1. Effect of cyanide on renal function

(Period no. 1 before, period no. 2 during the injection of cyanide into the left renal artery; R.K. = right kidney; L.K. = left kidney.)
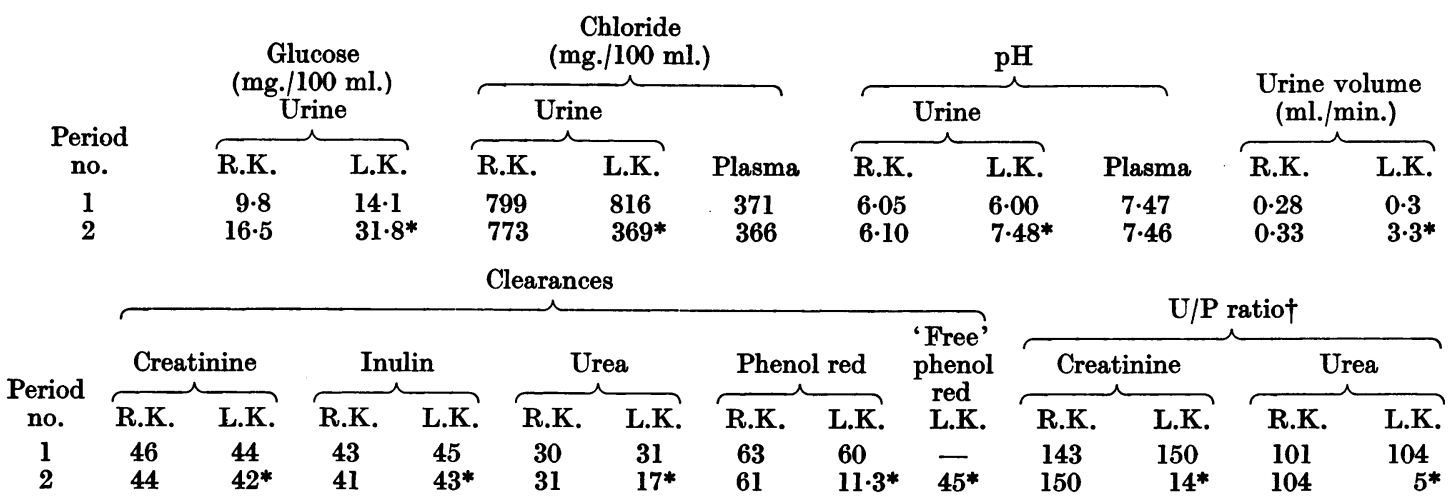

* Blood flowing through left kidney for this period contained $\mathrm{m} / 600$ sodium cyanide.

$\dagger$ Urine/plasma ratio.

Table 2. Effect of cyanide on certain renal functions

(Sodium cyanide (м/600) introduced into the blood going to the left kidney.

Right kidney served as control.)

\begin{tabular}{|c|c|c|c|c|c|c|c|c|c|c|c|c|c|c|}
\hline \multirow[b]{3}{*}{$\begin{array}{l}\text { Dog } \\
\text { no. }\end{array}$} & \multirow[b]{3}{*}{ Kidney } & \multirow{3}{*}{$\begin{array}{l}\text { Glucose } \\
\text { (mg./100 } \\
\text { ml.) }\end{array}$} & \multicolumn{10}{|c|}{ Chloride } & \multirow{2}{*}{\multicolumn{2}{|c|}{ U/P ratio* }} \\
\hline & & & \multicolumn{2}{|c|}{ (mg./100 ml.) } & \multicolumn{2}{|c|}{ pH } & \multirow{2}{*}{$\begin{array}{l}\text { Urine } \\
\text { volume } \\
\text { (ml./min.) }\end{array}$} & \multirow[b]{2}{*}{$\begin{array}{l}\text { Creat- } \\
\text { inine }\end{array}$} & \multirow[b]{2}{*}{ Inulin } & \multirow[b]{2}{*}{ Urea } & \multirow[b]{2}{*}{$\begin{array}{l}\text { Phenol } \\
\text { red }\end{array}$} & \multirow{2}{*}{$\begin{array}{c}\text { 'Free' } \\
\text { phenol } \\
\text { red }\end{array}$} & & \\
\hline & & & & & Urine & $\overbrace{\text { Plasma }}$ & & & & & & & $\begin{array}{l}\text { Creat- } \\
\text { inine }\end{array}$ & Urea \\
\hline 1 & $\begin{array}{l}\text { R. } \\
\text { L. }\end{array}$ & $\begin{array}{l}14 \cdot 1 \\
36 \cdot 5\end{array}$ & $\begin{array}{l}867 \\
400\end{array}$ & $\begin{array}{l}393 \\
399\end{array}$ & $\begin{array}{l}6 \cdot 13 \\
7 \cdot 40\end{array}$ & $\begin{array}{l}7 \cdot 43 \\
7 \cdot 42\end{array}$ & $\begin{array}{l}0 \cdot 47 \\
3 \cdot 87\end{array}$ & $\begin{array}{l}40 \\
38\end{array}$ & $\begin{array}{l}39 \\
37\end{array}$ & $\begin{array}{r}19 \\
9\end{array}$ & $\begin{array}{l}63 \\
8 \cdot 0\end{array}$ & $\overline{40}$ & $\begin{array}{l}85 \\
9 \cdot 8\end{array}$ & $\begin{array}{l}41 \\
2 \cdot 3\end{array}$ \\
\hline 2 & $\begin{array}{l}\text { R. } \\
\text { L. }\end{array}$ & $\begin{array}{l}11 \cdot 7 \\
28 \cdot 2\end{array}$ & $\begin{array}{l}799 \\
389\end{array}$ & $\begin{array}{l}385 \\
390\end{array}$ & $\begin{array}{l}5 \cdot 92 \\
7 \cdot 53\end{array}$ & $\begin{array}{l}7 \cdot 51 \\
7 \cdot 50\end{array}$ & $\begin{array}{l}0 \cdot 35 \\
3 \cdot 15\end{array}$ & $\begin{array}{l}52 \\
55\end{array}$ & $\begin{array}{l}54 \\
51\end{array}$ & $\begin{array}{l}30 \\
16\end{array}$ & $\begin{array}{l}85 \\
11 \cdot 7\end{array}$ & $\overline{49}$ & $\begin{array}{l}148 \\
17 \cdot 5\end{array}$ & $\begin{array}{c}86 \\
5 \cdot 1\end{array}$ \\
\hline 3 & $\begin{array}{l}\text { R. } \\
\text { L. }\end{array}$ & $\begin{array}{l}19 \cdot 8 \\
34 \cdot 1\end{array}$ & $\begin{array}{l}807 \\
396\end{array}$ & $\begin{array}{l}397 \\
400\end{array}$ & $\begin{array}{l}6 \cdot 76 \\
7 \cdot 43\end{array}$ & $\begin{array}{l}7 \cdot 39 \\
7 \cdot 41\end{array}$ & $\begin{array}{l}0.93 \\
4.65\end{array}$ & $\begin{array}{l}48 \\
50\end{array}$ & $\begin{array}{l}51 \\
49\end{array}$ & $\begin{array}{l}28 \\
16\end{array}$ & $\begin{array}{l}95 \\
13 \cdot 3\end{array}$ & $\overline{51}$ & $\begin{array}{l}52 \\
10 \cdot 8\end{array}$ & $\begin{array}{l}30 \\
3 \cdot 4\end{array}$ \\
\hline 4 & $\begin{array}{l}\text { R. } \\
\text { L. }\end{array}$ & $\begin{array}{r}8 \cdot 2 \\
15 \cdot 6\end{array}$ & $\begin{array}{l}826 \\
393\end{array}$ & $\begin{array}{l}387 \\
389\end{array}$ & $\begin{array}{l}5 \cdot 57 \\
\mathbf{7 \cdot 4 0}\end{array}$ & $\begin{array}{l}7 \cdot 44 \\
7 \cdot 42\end{array}$ & $\begin{array}{l}0 \cdot 40 \\
4 \cdot 18\end{array}$ & $\begin{array}{l}41 \\
38\end{array}$ & $\begin{array}{l}39 \\
35\end{array}$ & $\begin{array}{l}17 \\
10\end{array}$ & $\begin{array}{c}58 \\
8 \cdot 6\end{array}$ & $\overline{39}$ & $\begin{array}{l}103 \\
9 \cdot 1\end{array}$ & $\begin{array}{l}43 \\
2 \cdot 5\end{array}$ \\
\hline 5 & $\begin{array}{l}\text { R. } \\
\text { L. }\end{array}$ & $\begin{array}{l}16 \cdot 5 \\
31 \cdot 8\end{array}$ & $\begin{array}{l}846 \\
369\end{array}$ & $\begin{array}{l}371 \\
366\end{array}$ & $\begin{array}{l}6 \cdot 00 \\
7 \cdot 48\end{array}$ & $\begin{array}{l}\mathbf{7 \cdot 4 7} \\
\mathbf{7 \cdot 4 6}\end{array}$ & $\begin{array}{l}\mathbf{0} \cdot 30 \\
\mathbf{3} \cdot 30\end{array}$ & $\begin{array}{l}44 \\
42\end{array}$ & $\begin{array}{l}45 \\
43\end{array}$ & $\begin{array}{l}31 \\
17\end{array}$ & $\begin{array}{l}60 \\
11 \cdot 3\end{array}$ & $\overrightarrow{45}$ & $\begin{array}{r}150 \\
14\end{array}$ & $\begin{array}{l}103 \\
5 \cdot 2\end{array}$ \\
\hline 6 & $\begin{array}{l}\text { R. } \\
\text { L. }\end{array}$ & $\begin{array}{r}9 \cdot 4 \\
21 \cdot 0\end{array}$ & $\begin{array}{l}759 \\
390\end{array}$ & $\begin{array}{l}385 \\
384\end{array}$ & $\begin{array}{l}6 \cdot 24 \\
7 \cdot 45\end{array}$ & $\begin{array}{l}7 \cdot 48 \\
7 \cdot 47\end{array}$ & $\begin{array}{l}0.38 \\
4.51\end{array}$ & $\begin{array}{l}54 \\
47\end{array}$ & $\begin{array}{l}51 \\
47\end{array}$ & $\begin{array}{l}32 \\
17\end{array}$ & $\begin{array}{l}87 \\
12 \cdot 6\end{array}$ & $\overline{48}$ & $\begin{array}{l}142 \\
11 \cdot 1\end{array}$ & $\begin{array}{c}84 \\
3 \cdot 8\end{array}$ \\
\hline 7 & $\begin{array}{l}\text { R. } \\
\text { L. }\end{array}$ & $\begin{array}{r}8 \cdot 2 \\
22 \cdot 3\end{array}$ & $\begin{array}{l}859 \\
372\end{array}$ & $\begin{array}{l}383 \\
379\end{array}$ & $\begin{array}{l}6 \cdot 37 \\
7 \cdot 45\end{array}$ & $\begin{array}{l}7 \cdot 45 \\
7 \cdot 46\end{array}$ & $\begin{array}{l}1 \cdot 13 \\
5 \cdot 79\end{array}$ & $\begin{array}{l}\mathbf{5 5} \\
\mathbf{5 5}\end{array}$ & $\begin{array}{l}53 \\
54\end{array}$ & $\begin{array}{l}22 \\
12\end{array}$ & $\begin{array}{c}108 \\
14 \cdot 7\end{array}$ & $\overline{50}$ & $\begin{array}{l}49 \\
9 \cdot 5\end{array}$ & $\begin{array}{r}19 \cdot 5 \\
2 \cdot 1\end{array}$ \\
\hline 8 & $\begin{array}{l}\text { R. } \\
\text { L. }\end{array}$ & $\begin{array}{r}7 \cdot 0 \\
20.0\end{array}$ & $\begin{array}{l}907 \\
413\end{array}$ & $\begin{array}{l}403 \\
409\end{array}$ & $\begin{array}{l}6 \cdot 05 \\
7 \cdot 48\end{array}$ & $\begin{array}{l}7 \cdot 47 \\
7 \cdot 48\end{array}$ & $\begin{array}{l}0.45 \\
3 \cdot 97\end{array}$ & $\begin{array}{l}50 \\
52\end{array}$ & $\begin{array}{l}51 \\
50\end{array}$ & $\begin{array}{l}34 \\
18\end{array}$ & $\begin{array}{l}94 \\
13 \cdot 6\end{array}$ & $\overline{56}$ & $\begin{array}{c}111 \\
13 \cdot 1\end{array}$ & $\begin{array}{l}76 \\
4 \cdot 6\end{array}$ \\
\hline 9 & $\begin{array}{l}\text { R. } \\
\text { L. }\end{array}$ & $\begin{array}{l}10 \cdot 6 \\
25 \cdot 9\end{array}$ & $\begin{array}{l}778 \\
377\end{array}$ & $\begin{array}{l}382 \\
381\end{array}$ & $\begin{array}{l}5 \cdot 74 \\
7 \cdot 40\end{array}$ & $\begin{array}{l}7 \cdot 39 \\
7 \cdot 38\end{array}$ & $\begin{array}{l}0 \cdot 42 \\
4 \cdot 36\end{array}$ & $\begin{array}{l}80 \\
77\end{array}$ & $\begin{array}{l}81 \\
80\end{array}$ & $\begin{array}{l}46 \\
26\end{array}$ & $\begin{array}{l}127 \\
19 \cdot 6\end{array}$ & $\overline{86}$ & $\begin{array}{c}191 \\
17 \cdot 7\end{array}$ & $\begin{array}{l}109 \\
6 \cdot 5\end{array}$ \\
\hline 10 & $\begin{array}{l}\text { R. } \\
\text { L. }\end{array}$ & $\begin{array}{r}8 \cdot 2 \\
28 \cdot 2\end{array}$ & $\begin{array}{l}921 \\
415\end{array}$ & $\begin{array}{l}413 \\
410\end{array}$ & $\begin{array}{l}7 \cdot 92 \\
7 \cdot 55\end{array}$ & $\begin{array}{l}7 \cdot 54 \\
7 \cdot 53\end{array}$ & $\begin{array}{l}0 \cdot 87 \\
5 \cdot 23\end{array}$ & $\begin{array}{l}54 \\
50\end{array}$ & $\begin{array}{l}56 \\
53\end{array}$ & $\begin{array}{l}38 \\
20\end{array}$ & $\stackrel{112}{16 \cdot 1}$ & $\overline{55}$ & $\begin{array}{l}62 \\
9 \cdot 6\end{array}$ & $\begin{array}{l}44 \\
1 \cdot 8\end{array}$ \\
\hline 11 & $\begin{array}{l}\text { R. } \\
\text { L. }\end{array}$ & $\begin{array}{l}15 \cdot 7 \\
20 \cdot 0\end{array}$ & $\begin{array}{l}867 \\
392\end{array}$ & $\begin{array}{l}387 \\
389\end{array}$ & $\begin{array}{l}7 \cdot 98 \\
7 \cdot 53\end{array}$ & $\begin{array}{l}7 \cdot 53 \\
7 \cdot 54\end{array}$ & $\begin{array}{l}1 \cdot 07 \\
6 \cdot 43\end{array}$ & $\begin{array}{l}53 \\
56\end{array}$ & $\begin{array}{l}55 \\
53\end{array}$ & $\begin{array}{l}34 \\
19\end{array}$ & $\begin{array}{l}83 \\
11 \cdot 9\end{array}$ & $\overline{54}$ & $\begin{array}{c}50 \\
8 \cdot 7\end{array}$ & $\begin{array}{l}47 \\
1 \cdot 4\end{array}$ \\
\hline 12 & $\begin{array}{l}\text { R. } \\
\text { L. }\end{array}$ & $\begin{array}{r}9 \cdot 1 \\
15 \cdot 3\end{array}$ & $\begin{array}{l}883 \\
395\end{array}$ & $\begin{array}{l}389 \\
391\end{array}$ & $\begin{array}{l}7 \cdot 97 \\
7 \cdot 50\end{array}$ & $\begin{array}{l}7 \cdot 52 \\
7 \cdot 51\end{array}$ & $\begin{array}{l}0 \cdot 40 \\
5 \cdot 68\end{array}$ & $\begin{array}{l}46 \\
42\end{array}$ & $\begin{array}{l}47 \\
44\end{array}$ & $\begin{array}{l}30 \\
16\end{array}$ & $\begin{array}{l}86 \\
11 \cdot 7\end{array}$ & $\overline{48}$ & $\begin{array}{l}115 \\
7 \cdot 4\end{array}$ & $\begin{array}{l}75 \\
2 \cdot 8\end{array}$ \\
\hline
\end{tabular}

* Urine/plasma ratio. 
almost one half of the normal value. The 'total' phenol red clearance is only $15 \%$ of normal. When the phenol red clearance is calculated using the figure for 'free' phenol red in the plasma it is found to be practically the same as the creatinine and inulin clearances.

\section{DISCUSSION}

The main difference between the effect of cyanide on the isolated kidney as reported by Starling \& Verney (1925) and its effect on the kidney in situ lies in the continued ability of the latter to reabsorb glucose after poisoning with cyanide and in its ability to concentrate the urine to a considerable extent.

The fact that the clearance of creatinine and inulin is not changed during the period of cyanide action shows that the permeability of the cells to these two substances is unchanged. The marked decrease in urea clearances is presumptive evidence of increased back diffusion of this substance, as it is inconceivable that the glomerulus could become less permeable to urea and still filter inulin and creatinine at the normal rate. This increased back diffusion could be due to a change in cellular permeability for urea. It seems more likely, however, that the cells of the distal tubules and the collecting tubules have to perform work, involving the use of enzyme systems inhibited by cyanide, to prevent urea from diffusing back from the concentrated tubular urine, in contrast to inulin and creatinine which probably remain in the lumen of the tubules because the cell membranes are not permeable to these substances.

The marked diuresis is further evidence that the oxidative systems in the cells are necessary for the performance of much of the osmotic work of the kidney. On the other hand, reabsorption of normal amounts of glucose is little affected and can apparently proceed anaerobically. Whether or not the total ability to handle glucose is decreased was not determined, as we were unable to establish the glucose $T m$ (the maximum amount of glucose which the kidney can reabsorb in $1 \mathrm{~min}$.) in the short time in which it was practical to carry on the experiment, but it seems quite probable that this might be the case in view of the small but consistent increase in glucose in the urine, and the partial decrease in the ability of the kidney to concentrate the urine and to prevent the back diffusion of urea. The secretory powers of the kidney, at least in respect to phenol red excretion and ammonia formation, appear to be concerned with oxidative mechanisms as they are completely abolished by cyanide. The loss of the kidney's ability to change the $\mathrm{pH}$ of the urine from that of the glomerular filtrate may be explained on the basis of the mechanism of urinary acidification advanced by Pitts \& Alexander (1945), by the suspension of the oxidative metabolic processes within the tubular cells with a consequent lack of carbon dioxide for the formation of carbonic acid, the probable source of the hydrogen ions exchanged for the sodium ions in the tubular urine.

Poisoning of the kidney with cyanide therefore, which inhibits the action of some of the enzyme systems within the cell without producing morphological changes, does not alter the character of the tubular wall as a semi-permeable membrane, but does abolish a number of its secretory powers and markedly decreases the amount of osmotic work which can be performed.

\section{SUMMARY}

1. A method for perfusing one kidney in situ with cyanided blood, while using the other kidney as a control, is described.

2. The general concentrating power of the kidney poisoned with cyanide is only about one tenth that of the normal kidney and its ability to concentrate chloride is entirely lost.

3. Clearances of creatinine and inulin are unchanged, but the clearance of urea is decreased $50 \%$.

4. The tubular secretion of phenol red and ammonia is completely inhibited.

5. The kidney loses its ability to change the hydrogen-ion concentration of the glomerular filtrate.

6. The reabsorption of glucose is practically unaffected.

\section{REFERENCES}

Bobey, M. E., Longley, L. P., Dickes, R., Price, J. W. \& Hayman, J. M. (1942). Amer. J. Physiol. 139, 155.

Folin, O. \& Wu, H. (1919). J. biol. Chem. 38, 81.

Grollman, A. (1925). J. biol. Chem. 64, 141.

Harding, V. J. \& Downs, C. E. (1933). J. biol. Chem. 101, 1487.

Nicholson, T. F., Selby, D. L. \& Urquhart, R. W. I. (1938). J. exp. Med. 68, 439.

Peters, J. P. \& Van Slyke, D. D. (1931). Quantitative Clinical Chemistry, 2. Baltimore: Williams and Wilkins.
Pitts, R. F. \& Alexander, R. S. (1945). Amer. J. Physiol. $144,239$.

Sendroy, J. (1937). J. biol. Chem. 120, 335.

Shannon, J. A. (1935). Amer. J. Physiol. 113, 602.

Starling, E. H. \& Verney, E. B. (1925). Proc. Roy. Soc. B, 97, 321.

Van Slyke, D. D. \& Cullen, G. E. (1916). J.biol.Chem. 24, 117.

Van Slyke, D. D. \& Hawkins, J. A. (1928). J. biol. Chem. 79, 739.

West, E, S., Scharles, F. H. \& Peterson, V. L. (1929). J. biol. Chem. 82, 137. 